\title{
NMR Spectral Assignments and Hydrolysis Studies of Dulcosides A and B
}

\author{
Venkata Sai Prakash Chaturvedula (Corresponding Author) \\ Organic Chemistry Department, Global Research and Development \\ The Coca-Cola Company \\ One Coca-Cola Plaza, Atlanta, GA 30313, USA \\ Tel: 1-40-4676-9257 E-mail: vchaturvedula@coca-cola.com \\ Indra Prakash \\ Organic Chemistry Department, Global Research and Development \\ The Coca-Cola Company \\ One Coca-Cola Plaza, Atlanta, GA 30313, USA
}

Received: October 8, 2011

Accepted: October 26, 2011 Published: December 1, 2011

doi:10.5539/ijc.v3n4p32

URL: http://dx.doi.org/10.5539/ijc.v3n4p32

\begin{abstract}
The complete ${ }^{1} \mathrm{H}$ and ${ }^{13} \mathrm{C}$ NMR assignments for the two diterpene glycosides $13-[(2-O-\alpha$-L-rhamnopyranosyl - $\beta$-D-glucopyranosyl)oxy]-ent-kaur-16-en-19-oic acid $\beta$-D-glucopyranosyl ester (Dulcoside A) and 13-[(2-O- $\alpha$-L-rhamnopyranosyl-3-O- $\beta$-D-glucopyranosyl- $\beta$-D-glucopyranosyl)oxy]-ent-kaur-16-en-19-oic acid $\beta$-D-glucopyranosyl ester (Dulcoside B) isolated from Stevia rebaudiana were achieved by the extensive NMR $\left({ }^{1} \mathrm{H}\right.$ and $\left.{ }^{13} \mathrm{C}, \mathrm{COSY}, \mathrm{HSQC}, \mathrm{HMBC}\right)$ and mass spectral data. Further, hydrolysis of the two compounds Dulcosides $\mathrm{A}$ and $\mathrm{B}$ was performed using acid and enzymatic studies to identify their aglycone and sugar residues.
\end{abstract}

Keywords: Dulcoside A, Dulcoside B, Diterpenoid glycosides, 1D and 2D NMR spectral data, HRMS data, Acid and enzymatic hydrolysis

\section{Introduction}

Stevia rebaudiana (Bertoni) is a perennial shrub belonging to the family of Asteraceae (Compositae) which is native to Brazil and Paraguay; but now is grown commercially in a number of countries, particularly in Japan, Taiwan, Korea, Thailand and Indonesia (Mosettig et al., 1955; 1963). Extracts of the leaves of S. rebaudiana have been used for decades to sweeten food and beverages in Japan, South America and China. The major constituents in the leaves of $S$. rebaudiana are the potently sweet diterpenoid glycosides namely stevioside, and rebaudioside A, which are glycosides of the diterpene steviol, ent-13-hydroxykaur-16-en-19-oic acid (Brandle et al., 1998); also known as Stevia sweeteners. Stevioside tastes about 150-250 times sweeter than sucrose and rebaudioside A tastes about 200-300 times sweeter than sucrose; both are non-caloric.

In our continuing research to discover natural sweeteners, we have isolated several novel diterpene glycosides (Chaturvedula et al., 2011a-g) from the commercial extracts of $S$. rebaudiana obtained from various suppliers all over the World. Apart from isolating novel compounds and utilizing them as possible natural sweeteners or sweetness enhancers, we are also engaged in understanding the stability of the steviol glycosides in various systems of interest and characterization of degradation products using various spectroscopic analysis (Chaturvedula et al., 2011h-i), and their synthesis using naturally occurring starting materials (Chaturvedula et al., $2011 \mathrm{j})$. In this article, we are describing the complete ${ }^{1} \mathrm{H}$ and ${ }^{13} \mathrm{C}$ NMR spectral assignments for the two diterpene glycosides 13-[(2-O- $\alpha$-L-rhamnopyranosyl- $\beta$-D-glucopyranosyl)oxy]-ent-kaur-16-en-19-oic acid $\beta$-D-glucopyranosyl ester (Dulcoside A, 1) and 13-[(2-O- $\alpha$-L-rhamnopyranosyl-3- $O$ - $\beta$-D-glucopyranosyl- $\beta$-D-glucopyranosyl)oxy] -ent-kaur-16-en-19-oic acid $\beta$-D-glucopyranosyl ester (Dulcoside B, 2), also known as rebaudioside C that were identified from $S$. rebaudiana (Figure 1). The complete NMR assignments were achieved on the basis of $1 \mathrm{D}\left({ }^{1} \mathrm{H}\right.$ and ${ }^{13} \mathrm{C}$ ) and 2D (COSY, HSQC and HMBC) NMR as well as high resolution mass spectroscopic (MS) data. Acid 
and enzymatic hydrolysis studies were performed on compounds $\mathbf{1}$ and $\mathbf{2}$ to identify aglycone and sugar residues in their structures.

\section{Experimental}

\subsection{General Instrumentation Procedures}

Melting points were measured using a SRS Optimelt MPA 100 instrument and are uncorrected. HPLC analysis was performed using an Agilent (Wilmington, DE) 1200 system, including a quaternary pump, a temperature controlled column compartment with additional 6-port switching valve, an autosampler and a UV absorbance detector. The reversed phase (RP) HPLC was employed using a Phenomenex (Torrance, CA) Synergi-Hydro column $(250 \mathrm{~mm}$ x $4.6 \mathrm{~mm}, 4 \mu \mathrm{m})$ with a Phenomenex Security guard $\mathrm{C}_{18}$ cartridge and a tertiary solvent mobile phase (A: $0.040 \% \mathrm{NH}_{4} \mathrm{OAc} / \mathrm{AcOH}$ buffer, $\mathrm{B}$ : $\mathrm{MeCN}$ and C: $0.040 \% \mathrm{AcOH}$ ). The column was maintained at a temperature of $55{ }^{\circ} \mathrm{C}$ and the flow rate was $1.0 \mathrm{ml} /$ minute. Charged Aerosol Detector (CAD) was used for the purification of the steviol glycosides 1 and $\mathbf{2}$ with a total run time of 43 min (Table 1).

Analytical HPLC was carried out with a Waters 600E multisolvent delivery system using a Phenomenex Luna $\mathrm{C}_{18}$ $(150 \times 4.6 \mathrm{~mm}, 5 \mu \mathrm{m})$ column. IR spectral data was acquired using a Perkin Elmer 400 Fourier Transform Infrared (FT-IR) Spectrometer with Universal attenuated total reflectance (UATR) polarization accessory and NMR spectra were acquired on Varian Unity Plus $600 \mathrm{MHz}$ instruments using standard pulse sequences. The NMR spectra were acquired in $\mathrm{CD}_{3} \mathrm{OD}$ and $\mathrm{D}_{2} \mathrm{O}$ (9:1) mixture; chemical shifts are given in $\delta(\mathrm{ppm})$, and coupling constants are reported in Hz. HRMS and MS/MS data were generated with a Waters Premier Quadrupole Time-of-Flight (Q-TOF) mass spectrometer equipped with an electrospray ionization source operated in the positive-ion mode and Thermo Fisher Discovery OrbiTrap in the electrospray positive mode. Samples were diluted with water: acetonitrile (1:1) containing $0.1 \%$ formic acid and introduced via infusion using the onboard syringe pump.

\subsection{Plant Material}

SG95, the commercial aqueous extract consisting of a mixture of diterpenoid glycosides of the leaves of $S$. rebaudiana was obtained from the Pure Circle (Kuala Lumpur, Malaysia). The authenticity of the crude extract was confirmed by performing its retention time $\left(t_{R}\right)$ comparison with the internal standard compounds of known steviol glycosides namely rebaudioside A-D, and rubusoside isolated from $S$. rebaudiana using the preparative HPLC method as reported earlier (Clos et al., 2008). A voucher specimen is deposited at The Coca-Cola Company, No. VSPC-3166-002.

\subsection{Isolation and Characterization}

Compounds 1 and 2 were purified by using an Agilent HPLC 1200 system equipped with a Phenomenex Synergi-Hydro column $(250 \mathrm{~mm} \times 4.6 \mathrm{~mm}, 4 \mu \mathrm{m})$ with a Phenomenex Security guard $\mathrm{C}_{18}$ cartridge. Using the above mentioned HPLC method shown in Table 1, collected the peaks eluting at $t_{R} 12.37$ and $21.88 \mathrm{~min}$; and dried the corresponding solutions under nitrogen yielded $\mathbf{1}$ and $\mathbf{2}$ respectively.

\subsection{3-[(2-O- $\alpha$-L-rhamnopyranosyl- $\beta$-D-glucopyranosyl)oxy]-ent-kaur-16-en-19-oic acid $\beta$-D-glucopyranosyl} ester (Dulcoside A, 1)

White powder; mp 192 - $194{ }^{\circ} \mathrm{C}$; IR $v_{\max }: 3305,2945,1725,1050,900 \mathrm{~cm}^{-1} ;{ }^{1} \mathrm{H}-\mathrm{NMR}\left(600 \mathrm{MHz}, \mathrm{CD}_{3} \mathrm{OD}+\mathrm{D}_{2} \mathrm{O}\right.$, $\delta \mathrm{ppm})$ and ${ }^{13} \mathrm{C}-\mathrm{NMR}\left(150 \mathrm{MHz}, \mathrm{CD}_{3} \mathrm{OD}+\mathrm{D}_{2} \mathrm{O}, \delta \mathrm{ppm}\right)$ spectroscopic data see Table 2; HRMS $\left(\mathrm{M}+\mathrm{NH}_{4}\right)^{+} \mathrm{m} / z$ 806.4175 (calcd. for $\mathrm{C}_{38} \mathrm{H}_{64} \mathrm{O}_{17} \mathrm{~N}$ : 806.4174); (M+Na) ${ }^{+} m / z 811.3718$ (calcd. for $\mathrm{C}_{38} \mathrm{H}_{60} \mathrm{O}_{17} \mathrm{Na}$ : 811.3728).

2.5 13-[(2-O- $\alpha$-L-rhamnopyranosyl-3-O- $\beta$-D-glucopyranosyl- $\beta$-D-glucopyranosyl)oxy]-ent-kaur-16-en-19-oic acid $\beta$-D-glucopyranosyl ester (Dulcoside B/Rebaudioside C, 2)

White powder; $\mathrm{mp} 233-235^{\circ} \mathrm{C}$; IR $v_{\max }: 3350,2925,1723,1035,895 \mathrm{~cm}^{-1} ;{ }^{1} \mathrm{H}-\mathrm{NMR}\left(600 \mathrm{MHz}, \mathrm{CD}_{3} \mathrm{OD}+\mathrm{D}_{2} \mathrm{O}, \delta\right.$ ppm) and ${ }^{13} \mathrm{C}$-NMR $\left(150 \mathrm{MHz}, \mathrm{CD}_{3} \mathrm{OD}+\mathrm{D}_{2} \mathrm{O}, \delta \mathrm{ppm}\right)$ spectroscopic data see Table 2; HRMS $\left(\mathrm{M}+\mathrm{NH}_{4}\right)^{+} \mathrm{m} / z$ 968.4705 (calcd. for $\mathrm{C}_{44} \mathrm{H}_{74} \mathrm{O}_{22} \mathrm{~N}$ : 968.4702); (M+Na) ${ }^{+} \mathrm{m} / z$ 973.4255 (calcd. for $\mathrm{C}_{44} \mathrm{H}_{70} \mathrm{O}_{22} \mathrm{Na}$ : 973.4276).

\subsection{General procedure for acid hydrolysis of $\mathbf{1}$ and $\mathbf{2}$}

To a solution of each compound of $\mathbf{1}$ and $\mathbf{2}(250 \mu \mathrm{g})$ in $\mathrm{MeOH}(1 \mathrm{ml})$ was added $1 \mathrm{ml}$ of $5 \% \mathrm{H}_{2} \mathrm{SO}_{4}$ and the mixture was refluxed for 8 hours. The reaction mixture was then neutralized with saturated sodium carbonate and extracted with ethyl acetate (EtOAc) $(2 \times 5 \mathrm{ml})$ to give an aqueous fraction containing sugars and an EtOAc fraction containing the aglycone part. The aqueous phase was concentrated and compared with standard sugars using the TLC systems EtOAc/n-butanol/water (2:7:1) and $\mathrm{CH}_{2} \mathrm{Cl}_{2} / \mathrm{MeOH} /$ water (10:6:1) (Bedir et al., 2001; Chaturvedula et al., 2003; Huan et al., 1998); the two sugars were identified as rhamnose and glucose for both the hydrolyzed products of $\mathbf{1}$ and $\mathbf{2}$. 


\subsection{General procedure for acid hydrolysis and determination of sugar configuration in $\mathbf{1}$ and $\mathbf{2}$}

Each compound 1 and $2(500 \mu \mathrm{g})$ was hydrolyzed with $0.5 \mathrm{M} \mathrm{HCl}(0.5 \mathrm{~mL})$ for $1.5 \mathrm{~h}$. After cooling, the mixture was passed through an Amberlite IRA400 column and the eluate was lyophilized. The residue was dissolved in pyridine $(0.25 \mathrm{~mL})$ and heated with L-cysteine methyl ester $\mathrm{HCl}(2.5 \mathrm{mg})$ at $60{ }^{\circ} \mathrm{C}$ for $1.5 \mathrm{~h}$, and then $O$-tolyl isothiocyanate $(12.5 \mathrm{uL})$ was added to the mixture and heated at $60{ }^{\circ} \mathrm{C}$ for an additional $1.5 \mathrm{~h}$. The reaction mixture

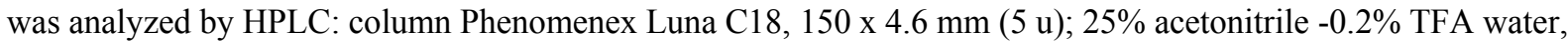
$1 \mathrm{~mL} / \mathrm{min}$; UV detection at $250 \mathrm{~nm}$. The sugars were identified as D-glucose $(t \mathrm{R}, 12.24 \mathrm{~min})$ and L-rhamnose $(t \mathrm{R}$, $21.26 \mathrm{~min}$ ) [authentic samples, D-glucose $(t \mathrm{R}, 12.35)$ and L-glucose $(t \mathrm{R}, 11.12 \mathrm{~min})$; D- rhamnose $(t \mathrm{R}, 11.73)$ and L- rhamnose ( $t \mathrm{R}, 21.64 \mathrm{~min})]$ (Tanaka et al., 2007).

\subsection{Enzymatic hydrolysis of $\mathbf{1}$ and $\mathbf{2}$}

Each compound 1 and $2(250 \mu \mathrm{g})$ was dissolved in $2.5 \mathrm{ml}$ of $0.1 \mathrm{M}$ sodium acetate buffer, $\mathrm{pH} 4.5$ and crude pectinase from Aspergillus niger (50 uL, Sigma-Aldrich, P2736) was added. The mixture was stirred at $50{ }^{\circ} \mathrm{C}$ for $48 \mathrm{hr}$. The product precipitated out during the reaction and was filtered and then crystallized. The resulting product obtained from the hydrolysis of $\mathbf{1}$ and $\mathbf{2}$ was identified as steviol by comparison of its co-TLC with standard compound and ${ }^{1} \mathrm{H}$ NMR spectral data (Ohtani et al., 1992).

\section{Results and Discussion}

Compound $\mathbf{1}$ was isolated as white powder and its molecular formula has been deduced as $\mathrm{C}_{38} \mathrm{H}_{60} \mathrm{O}_{17}$ on the basis of its HRMS data which showed the presence of an $\left[\mathrm{M}+\mathrm{NH}_{4}\right]^{+}$ion at $\mathrm{m} / z 806.4175$ together with $[\mathrm{M}+\mathrm{Na}]^{+}$adduct at $m / z$ 811.3718, this composition was supported by the ${ }^{13} \mathrm{C}$ NMR spectral data. The ${ }^{1} \mathrm{H}$ NMR spectrum of 1 showed the presence of two methyl singlets at $\delta 0.97$ and 1.22, two olefinic protons as singlets at $\delta 4.88$ and 5.13 of an exocyclic double bond, nine methylene and two methine protons between $\delta 0.86-2.17$ characteristic for the diterpenes belongs to the class of ent-kaurenes isolated earlier from the genus Stevia (Chaturvedula et al., 2011a-g). The basic skeleton of ent-kaurene diterpenoids was supported by the COSY $(\mathrm{H}-1 / \mathrm{H}-2 ; \mathrm{H}-2 / \mathrm{H}-3 ; \mathrm{H}-5 / \mathrm{H}-6$; H-6/H-7; H-9/H-11; H-11/H-12) and HMBC (H-1/C-2, C-10; H-3/C-1, C-2, C-4, C-5, C-18, C-19; H-5/C-4, C-6, C-7, C-9, C-10, C-18, C-19, C-20; H-9/C-8, C-10, C-11, C-12, C-14, C-15; H-14/C-8, C-9, C-13, C-15, C-16 and H-17/C-13, $\mathrm{C}-15, \mathrm{C}-16)$ correlations. The ${ }^{1} \mathrm{H}$ NMR of $\mathbf{1}$ also showed the presence of three anomeric protons observed at $\delta 4.65$, 5.30 and 5.34 in its ${ }^{1} \mathrm{H}$ NMR spectral data suggesting three sugar residues in its structure. This was further supported by the fragment ions observed in the positive ESI mode MS/MS spectrum of 1 which provided fragment ions corresponding to the sequential loss of three sugar residues to yield the fragment ions at $\mathrm{m} / z 627,465$, and 319 ; two hexoses and a deoxyhexose. Acid hydrolysis of 1 with $5 \% \mathrm{H}_{2} \mathrm{SO}_{4}$ afforded glucose and rhamnose which were identified by direct comparison with authentic samples (Bedir et al., 2001; Chaturvedula et al., 2003; Huan et al., 1998); confirming the presence of two glucose and one rhamnose moieties in its structure. Enzymatic hydrolysis of 1 furnished a compound which was found identical to ent-13-hydroxykauran-16-en-19-oic acid (steviol) on the basis of NMR spectral data comparison (Ohtani et al., 1992).

The identification of sugars present in $\mathbf{1}$ and their configurations were achieved by preparing their thiocarbamoyl-thiazolidine carboxylate derivatives with L-cysteine methyl ester and $O$-tolyl isothiocyanate, and in comparison of their retention times with the standard sugars as described in the literature; suggesting the sugar moieties present as $\beta$-D-glucopyranosyl and $\alpha$-L-rhamnopyranosyl units (Tanaka et al., 2007). The ${ }^{1} \mathrm{H}$ - and ${ }^{13} \mathrm{C}-\mathrm{NMR}$ values for all the protons and carbons were assigned on the basis of COSY, HSQC and HMBC correlations (Table 2). A close comparison of the ${ }^{1} \mathrm{H}$ and ${ }^{13} \mathrm{C}$ NMR values of $\mathbf{1}$ with those of stevioside (3) suggested the presence of three sugar units attached as a 2-O- $\alpha$-L-rhamnopyranosyl substituted $\beta$-D-glucopyranosyl substituent at C-13 hydroxyl and an additional $\beta$-D-glucosyl moiety at C-19 acid as an ester on steviol (Avent et al., 1990; Ohta et al., 2010), which was supported from the key COSY and HMBC correlations shown as in Figure 2. The large coupling constants observed for the two anomeric protons of the glucose moieties at $\delta 4.65(\mathrm{~d}, J=8.2 \mathrm{~Hz})$, and $5.34(\mathrm{~d}, J=8.2 \mathrm{~Hz})$, suggested their $\beta$-orientation as in steviol glycosides isolated from $S$. rebaudiana (Chaturvedula et al., 2011a-g). The third anomeric proton which was appeared at $\delta 5.30$ had a coupling constant of $1.2 \mathrm{~Hz}$ indicating the $\alpha$-configuration of the L-rhamnosyl unit (Ohta et al., 2010). Thus, the structure of 1 was deduced as 13-[(2-O- $\alpha$-L-rhamnopyranosyl- $\beta$-D-glucopyranosyl)oxy]-ent-kaur-16-en-19-oic acid $\beta$-D-glucopyranosyl ester (Dulcoside A).

The molecular formula of compound 2 was deduced as $\mathrm{C}_{44} \mathrm{H}_{70} \mathrm{O}_{22}$ from its HRMS data which showed $\left[\mathrm{M}+\mathrm{NH}_{4}\right]^{+}$ and $[\mathrm{M}+\mathrm{Na}]^{+}$adduct ions at $\mathrm{m} / \mathrm{z} 968.4705$ and 973.4255 respectively. The ${ }^{1} \mathrm{H}$ NMR spectrum of 2 also showed the presence of two methyl singlets at $\delta 0.98$, and 1.21, nine methylene and two methine protons, similar to $\mathbf{1}$ (Table 2). The ${ }^{1} \mathrm{H}$ NMR of 2 also showed the presence of four anomeric protons as doublets at $\delta 4.52,4.62,5.32$, and 5.40, suggesting the presence four sugar residues in its structure; which was further supported by the fragment ions 
observed in the positive ESI mode MS/MS spectrum of 2 that provided fragment ions corresponding to the sequential loss of three hexose and a deoxyhexose unit respectively at $m / z 789,627,465$, and 319 . Acid hydrolysis of $\mathbf{2}$ afforded sugar units which were identified as glucose and rhamnose and their configurations were assigned as $\beta$ and $\alpha$ respectively by preparing their corresponding thiocarbamoyl-thiazolidine carboxylate derivatives as described in 1. Enzymatic hydrolysis of $\mathbf{2}$ furnished steviol similar to $\mathbf{1}$ suggesting their identical basic skeleton of aglycone in both compounds.

From the hydrolysis experiments and NMR spectral data for $\mathbf{2}$, it was suggested that this compound is also having steviol backbone with three $\beta$-D-glucosyl substituents and an $\alpha$-L-rhamnosyl moiety in its structure. The ${ }^{1} \mathrm{H}$ and ${ }^{13} \mathrm{C}$ NMR values for all the protons and carbons were assigned on the basis of COSY, HSQC, and HMBC correlations and were shown in Table 2. A close comparison of the ${ }^{1} \mathrm{H}$ and ${ }^{13} \mathrm{C}$ NMR values of $\mathbf{2}$ with $\mathbf{1}$ as well as stevioside (3) and rebaudioside-A (4) suggested the presence of additional $\beta$-D-glucosyl at C-3" position of sugar II (Ohta et al., 2010; Wayne et al., 2009). This was supported by the HMBC correlations as shown in Figure 3. The large coupling constants observed for the three anomeric protons of the D-glucosyl moieties at $\delta 4.52(\mathrm{~d}, J=7.4$ $\mathrm{Hz}), 4.62(\mathrm{~d}, J=8.2 \mathrm{~Hz})$, and $5.32(\mathrm{~d}, J=8.2 \mathrm{~Hz})$, suggested their $\beta$-orientation whereas for the anomeric proton appeared at $\delta 5.40$ with coupling constant $1.2 \mathrm{~Hz}$ suggested its $\alpha$-orientation like $\mathbf{1}$. Based on the results from chemical and spectral studies, $\mathbf{2}$ was assigned as 13-[(2-O- $\alpha$-L-rhamnopyranosyl-3-O- $\beta$-D-glucopyranosyl- $\beta$-D-glucopyranosyl)oxy]-ent-kaur-16-en-19-oic acid $\beta$-D-glucopyranosyl ester (Dulcoside B).

\section{Conclusion}

We are herewith reporting the complete ${ }^{1} \mathrm{H}$ and ${ }^{13} \mathrm{C}$ NMR spectral assignments for the two ent-kaurane diterpenoids 13-[(2-O- $\alpha$-L-rhamnopyranosyl- $\beta$-D-glucopyranosyl)oxy]-ent-kaur-16-en-19-oic acid $\beta$-D-glucopyranosyl ester (Dulcoside A, 1) and 13-[(2-O- $\alpha$-L-rhamnopyranosyl-3-O- $\beta$-D-glucopyranosyl- $\beta$-D -glucopyranosyl)oxy]-ent-kaur-16-en-19-oic acid $\beta$-D-glucopyranosyl ester (Dulcoside B, 2) that were assigned on the basis of extensive 1D and 2D NMR as well as high resolution mass spectral data, which were supported by the acid and enzymatic hydrolysis studies.

\section{Acknowledgements}

We wish to thank AMRI, Bothell, WA, USA for obtaining some selected spectral data and Chris Mubarak, Analytical Sciences Department, The Coca-Cola Company, Atlanta, GA for providing IR spectral data.

\section{References}

Avent, A. G., Hanson, J. R., \& DeOliviera, B. H. (1990). Hydrolysis of the diterpenoid glycoside, Stevioside. Phytochemistry, 29, 2712-2715. http://dx.doi.org/10.1016/0031-9422(90)85225-5

Bedir, E., Toyang, N. J., Khan, I.A., Walker, L.A., \& Clark, A.M. (2001). A new dammarane type triterpene glycoside from Polyscias fulva. Journal of Natural Products, 64, 95-97. http://dx.doi.org/10.1021/np0003589

Brandle, J. E., Starrratt, A.N., \& Gijen, M. (1998). Stevia rebaudiana: its agricultural, biological and chemical properties. Canadian Journal of Plant Science, 78, 527-536. http://dx.doi.org/10.4141/P97-114

Chaturvedula, V. S. P., Schilling, J. K., Miller, J. S., Andriantsiferana, R., Rasamison, V. E., \& Kingston, D. G. I. (2003). New cytotoxic oleanane saponins from the infructescences of Polyscias amplifolia from the Madagascar rainforest. Planta Medica, 69, 440-444. http://dx.doi.org/10.1055/s-2003-39711

Chaturvedula, V. S. P., Mani, U., \& Prakash, I. (2011a). Diterpene glycosides from Stevia rebaudiana. Molecules, 16, 3552-3562. http://dx.doi.org/10.3390/molecules 16053552

Chaturvedula V. S. P., \& Prakash, I. (2011b). A new diterpenoid glycoside from Stevia rebaudiana. Molecules, 16 , 2937-2943. http://dx.doi.org/10.3390/molecules 16042937

Chaturvedula V. S. P., \& Prakash, I. (2011c). Structures of the novel diterpene glycosides from Stevia rebaudiana. Carbohydrate Research, 346, 1057-1060. http://dx.doi.org/10.1016/j.carres.2011.03.025

Chaturvedula V. S. P., Rhea, J., Milanowski, D., Mocek, U., \& Prakash, I. (2011d). Two minor diterpene glycosides from the leaves of Stevia rebaudiana. Natural Product Communications, 6, 175-178.

Chaturvedula V. S. P., Clos, J. F., Rhea, J., Milanowski, D., Mocek, U., DuBois, G. E., \& Prakash, I. (2011e). Minor diterpene glycosides from the leaves of Stevia rebaudiana. Phytochemistry Letters, 4, 209-212. http://dx.doi.org/10.1016/j.phytol.2011.01.002

Chaturvedula V. S. P., \& Prakash, I. (2011f). Additional minor diterpene glycosides from Stevia rebaudiana. Natural Product Communications, 6, 1059-1062. 
Chaturvedula, V. S. P., Mani, U., \& Prakash, I. (2011g). Structures of the novel $\alpha$-glucosyl linked diterpene glycosides from Stevia rebaudiana. Carbohydrate Research, 346, 2034-2038. http://dx.doi.org/10.1016/j.carres.2011.06.023

Chaturvedula V. S. P., Clos, J. F., \& Prakash, I. (2011 h). Stability study of steviol glycosides in mock beverages using fluorescent light exposure under ICH guidelines. International Journal of Pharmacy and Pharmaceutical Sciences, 3, 316-323.

Chaturvedula V. S. P., \& Prakash, I. (2011i). Isolation and NMR spectral assignments of steviolbioside and stevioside. International Journal of Research in Ayurveda and Pharmacy, 2, 1395-1401.

Chaturvedula, V. S. P., Klucik, J., Mani, U., \& Prakash, I. (2011j). Synthesis of ent-kaurane diterpene glycosides. Molecules, 16, 8402-8409. http://dx.doi.org/10.3390/molecules16108402

Clos, J. F., DuBois, G. E., \& Prakash, I. (2008). Photostability of Rebaudioside A and Stevioside in Beverages. Journal of Agricultural and Food Chemistry, 56, 8507-8513. http://dx.doi.org/10.1021/jf801343e

Huan, V.D., Yamamura, S., Ohtani, K., Kasai, R., Yamasaki, K., \& Nham, N.T. (1998) Oleanane saponins from Polyscias fructicosa. Phytochemistry, 47, 451-457. http://dx.doi.org/10.1016/S0031-9422(97)00618-3

Mosettig, E., \& Nes, W. R. (1955). Stevioside. II. The structure of the aglucon. Journal of Organic Chemistry, 20, 884-899. http://dx.doi.org/10.1021/jo01125a013

Mosettig, E., Beglinger, U., Dolder, F., Lichiti, H., Quitt, P., \& Waters, J. A. (1963). The absolute configuration of steviol and isosteviol. Journal of American Chemical Society, 85, 2305. http://dx.doi.org/10.1021/ja00898a025

Ohta, M., Sasa, S., Inoue, A., Tamai, T., Fujita, I., Morita, K., \& Matsuura, F. (2010). Characterization of novel steviol glycosides from leaves of Stevia rebaudiana Morita, Journal of Applied Glycoscience, 57, 199-209. http://dx.doi.org/10.5458/jag.57.199

Ohtani, K., Aikawa, Y., Kasai, R., Chou, W., Yamasaki, K., \& Tanaka, O. (1992). Minor diterpene glycosides from sweet leaves of Rubus suavissimus. Phytochemistry, 31, 1553-1559. http://dx.doi.org/10.1016/0031-9422(92)83105-8

Tanaka, T., Nakashim, T., Ueda, T., Tomii, K., \& Kouno, I. (2007). Facile discrimination of aldose enantiomers by reversed-phase HPLC. Chemical and Pharmaceutical Bulletin, 55, 899-901. http://dx.doi.org/10.1248/cpb.55.899

Wayne, E. S., \& Lin, L. (2009). NMR studies of the conformation of the natural sweetener rebaudioside A. Carbohydrate Research, 344, 2533-2538. http://dx.doi.org/10.1016/j.carres.2009.10.005

Table 1. RP-HPLC method for the purification of dulcoside A (1) and dulcoside B (2)

\begin{tabular}{|c|c|c|c|}
\hline Time (min) & \% of Mobile Phase A & \% of Mobile Phase B & \% of Mobile Phase C \\
\hline 0.0 & 75 & 25 & 0 \\
\hline 8.5 & 75 & 25 & 0 \\
\hline 10.0 & 71 & 29 & 0 \\
\hline 16.5 & 70 & 30 & 66 \\
\hline 18.5 & 0 & 34 & 66 \\
\hline 24.5 & 0 & 34 & 48 \\
\hline 26.5 & 0 & 52 & 48 \\
\hline 29.0 & 0 & 52 & 30 \\
\hline 31.0 & 0 & 70 & 30 \\
\hline 37.0 & 0 & 70 & 10 \\
\hline 37.1 & 0 & 90 & 10 \\
\hline 40.0 & 0 & 90 & 0 \\
\hline 40.1 & 75 & 25 & 0 \\
\hline 43.0 & 75 & 25 & \\
\hline
\end{tabular}


Table 2. ${ }^{1} \mathrm{H}$ and ${ }^{13} \mathrm{C}$ NMR chemical shift values for $\mathbf{1}-\mathbf{2}$ recorded in $\mathrm{CD}_{3} \mathrm{OD}+\mathrm{D}_{2} \mathrm{O}(9: 1)^{\mathrm{a}-\mathrm{c}}$

\begin{tabular}{|c|c|c|c|c|}
\hline \multirow{2}{*}{ Position } & \multicolumn{2}{|c|}{1} & \multicolumn{2}{|c|}{2} \\
\hline & ${ }^{1} \mathbf{H}$ & ${ }^{13} \mathrm{C}$ & ${ }^{1} \mathbf{H}$ & ${ }^{13} \mathrm{C}$ \\
\hline 1 & $\begin{array}{l}0.86(\mathrm{~m}, 1 \mathrm{H}) \\
1.87(\mathrm{~m}, 1 \mathrm{H})\end{array}$ & 41.8 & $\begin{array}{c}0.86(\mathrm{~m}, 1 \mathrm{H}) \\
1.86(\mathrm{~m}, 1 \mathrm{H})\end{array}$ & 42.0 \\
\hline 2 & $\begin{array}{l}1.41(\mathrm{~m}, 1 \mathrm{H}), \\
1.92(\mathrm{~m}, 1 \mathrm{H})\end{array}$ & 20.0 & $\begin{array}{l}1.40(\mathrm{~m}, 1 \mathrm{H}), \\
1.90(\mathrm{~m}, 1 \mathrm{H})\end{array}$ & 20.2 \\
\hline 3 & $\begin{array}{l}1.05(\mathrm{~m}, 1 \mathrm{H}), \\
2.15(\mathrm{~m}, 1 \mathrm{H})\end{array}$ & 39.1 & $\begin{array}{l}1.03(\mathrm{~m}, 1 \mathrm{H}), \\
2.16(\mathrm{~m}, 1 \mathrm{H})\end{array}$ & 39.5 \\
\hline 4 & & 43.5 & & 43.8 \\
\hline 5 & $1.14(\mathrm{~d}, 12.1,1 \mathrm{H})$ & 58.6 & $1.12(\mathrm{~d}, 11.9,1 \mathrm{H})$ & 57.3 \\
\hline 6 & $\begin{array}{l}1.85(\mathrm{~m}, 1 \mathrm{H}), \\
2.06(\mathrm{~m}, 1 \mathrm{H})\end{array}$ & 22.9 & $\begin{array}{l}1.82(\mathrm{~m}, 1 \mathrm{H}), \\
2.04(\mathrm{~m}, 1 \mathrm{H})\end{array}$ & 21.8 \\
\hline 7 & $\begin{array}{l}1.42(\mathrm{~m}, 1 \mathrm{H}), \\
1.57(\mathrm{~m}, 1 \mathrm{H})\end{array}$ & 42.6 & $\begin{array}{l}1.43(\mathrm{~m}, 1 \mathrm{H}), \\
1.55(\mathrm{~m}, 1 \mathrm{H})\end{array}$ & 42.9 \\
\hline 8 & & 41.8 & & 42.0 \\
\hline 9 & $0.96(\mathrm{~m}, 1 \mathrm{H})$ & 55.1 & $0.98(\mathrm{~m}, 1 \mathrm{H})$ & 53.9 \\
\hline 10 & & 40.8 & & 40.6 \\
\hline 11 & $\begin{array}{l}1.64(\mathrm{~m}, 1 \mathrm{H}) \\
1.82(\mathrm{~m}, 1 \mathrm{H})\end{array}$ & 21.5 & $\begin{array}{l}1.65(\mathrm{~m}, 1 \mathrm{H}), \\
1.80(\mathrm{~m}, 1 \mathrm{H})\end{array}$ & 21.6 \\
\hline 12 & $\begin{array}{l}1.52(\mathrm{~m}, 1 \mathrm{H}), \\
1.97(\mathrm{~m}, 1 \mathrm{H})\end{array}$ & 38.7 & $\begin{array}{c}1.50(\mathrm{~m}, 1 \mathrm{H}), \\
1.96(\mathrm{~m}, 1 \mathrm{H})\end{array}$ & 37.7 \\
\hline 13 & & 88.1 & & 87.8 \\
\hline 14 & $\begin{array}{c}1.52(\mathrm{~m}, 1 \mathrm{H}) \\
2.17(\mathrm{~d}, 11.4,1 \mathrm{H})\end{array}$ & 45.1 & $\begin{array}{c}1.48(\mathrm{~m}, 1 \mathrm{H}) \\
2.15(\mathrm{~d}, 11.2,1 \mathrm{H})\end{array}$ & 45.2 \\
\hline 15 & $\begin{array}{l}2.04(\mathrm{~d}, 16.5,1 \mathrm{H}), \\
2.14(\mathrm{~d}, 16.7,1 \mathrm{H})\end{array}$ & 48.5 & $\begin{array}{c}2.02(\mathrm{~d}, 16.2,1 \mathrm{H}), \\
2.16(\mathrm{~d}, 16.4,1 \mathrm{H})\end{array}$ & 48.4 \\
\hline 16 & & 154.1 & & 152.5 \\
\hline 17 & $\begin{array}{l}4.88(\mathrm{~s}, 1 \mathrm{H}) \\
5.13(\mathrm{~s}, 1 \mathrm{H})\end{array}$ & 106.0 & $\begin{array}{l}4.90(\mathrm{~s}, 1 \mathrm{H}) \\
5.16(\mathrm{~s}, 1 \mathrm{H})\end{array}$ & 105.1 \\
\hline 18 & $1.22(\mathrm{~s}, 3 \mathrm{H})$ & 28.8 & $1.21(\mathrm{~s}, 3 \mathrm{H})$ & 27.5 \\
\hline 19 & & 179.2 & & 177.8 \\
\hline 20 & $0.97(\mathrm{~s}, 3 \mathrm{H})$ & 16.2 & $0.98(\mathrm{~s}, 3 \mathrm{H})$ & 14.9 \\
\hline $1^{\prime}$ & $5.34(\mathrm{~d}, 8.2,1 \mathrm{H})$ & 95.9 & $5.32(\mathrm{~d}, 8.2,1 \mathrm{H})$ & 94.7 \\
\hline $2^{\prime}$ & $3.36(\mathrm{~m}, 1 \mathrm{H})$ & 74.0 & $3.37(\mathrm{~m}, 1 \mathrm{H})$ & 73.9 \\
\hline $3^{\prime}$ & $3.43(\mathrm{~m}, 1 \mathrm{H})$ & 77.5 & $3.43(\mathrm{~m}, 1 \mathrm{H})$ & 77.6 \\
\hline $4^{\prime}$ & $3.32(\mathrm{~m}, 1 \mathrm{H})$ & 70.0 & $3.32(\mathrm{~m}, 1 \mathrm{H})$ & 70.2 \\
\hline $5^{\prime}$ & $3.36(\mathrm{~m}, 1 \mathrm{H})$ & 77.5 & $3.36(\mathrm{~m}, 1 \mathrm{H})$ & 77.6 \\
\hline $6^{\prime}$ & $\begin{array}{l}3.67(\mathrm{~m}, 1 \mathrm{H}), \\
3.80(\mathrm{~m}, 1 \mathrm{H})\end{array}$ & 61.4 & $\begin{array}{l}3.68(\mathrm{~m}, 1 \mathrm{H}), \\
3.82(\mathrm{~m}, 1 \mathrm{H})\end{array}$ & 61.3 \\
\hline $1 "$ & $4.65(\mathrm{~d}, 8.2,1 \mathrm{H})$ & 97.3 & $4.62(\mathrm{~d}, 8.2,1 \mathrm{H})$ & 97.0 \\
\hline
\end{tabular}




\begin{tabular}{|c|c|c|c|c|}
\hline $2^{\prime \prime}$ & $3.44(\mathrm{~m}, 1 \mathrm{H})$ & 79.9 & $3.57(\mathrm{~m}, 1 \mathrm{H})$ & 79.3 \\
\hline $3^{\prime \prime}$ & $3.56(\mathrm{~m}, 1 \mathrm{H})$ & 78.4 & $3.76(\mathrm{~m}, 1 \mathrm{H})$ & 87.2 \\
\hline $4^{\prime \prime}$ & $3.34(\mathrm{~m}, 1 \mathrm{H})$ & 72.1 & $3.45(\mathrm{~m}, 1 \mathrm{H})$ & 72.8 \\
\hline $5^{\prime \prime}$ & $3.30(\mathrm{~m}, 1 \mathrm{H})$ & 78.7 & $3.28(\mathrm{~m}, 1 \mathrm{H})$ & 77.2 \\
\hline $6^{\prime \prime}$ & $3.67(\mathrm{~m}, 1 \mathrm{H})$, & 62.9 & $3.56(\mathrm{~m}, 1 \mathrm{H})$, & 61.6 \\
\hline $1^{\prime \prime \prime}$ & $3.88(\mathrm{~m}, 1 \mathrm{H})$ & & $3.78(\mathrm{~m}, 1 \mathrm{H})$ & \\
\hline $2^{\prime \prime \prime}$ & $3.30(\mathrm{~d}, 1.2,1 \mathrm{H})$ & 102.1 & $5.40(\mathrm{~d}, 1.2,1 \mathrm{H})$ & 100.9 \\
\hline $3^{\prime \prime \prime}$ & $3.60(\mathrm{~m}, 1 \mathrm{H})$ & 70.9 & $3.84(\mathrm{~m}, 1 \mathrm{H})$ & 70.8 \\
\hline $4^{\prime \prime \prime}$ & $3.47(\mathrm{~m}, 1 \mathrm{H})$ & 74.0 & $3.62(\mathrm{~m}, 1 \mathrm{H})$ & 72.7 \\
\hline $5^{\prime \prime \prime}$ & $3.82(\mathrm{~m}, 1 \mathrm{H})$ & 70.0 & $3.82(\mathrm{~m}, 1 \mathrm{H})$ & 73.9 \\
\hline $6^{\prime \prime \prime}$ & $1.25(\mathrm{~d}, 6.3,3 \mathrm{H})$ & 18.2 & $1.24(\mathrm{~d}, 6.3,3 \mathrm{H})$ & 70.6 \\
\hline $1^{\prime \prime \prime \prime}$ & & & $4.52(\mathrm{~d}, 7.4,1 \mathrm{H})$ & 103.7 \\
\hline $2^{\prime \prime \prime \prime}$ & & & $3.25(\mathrm{~m}, 1 \mathrm{H})$ & 75.8 \\
\hline $3^{\prime \prime \prime \prime}$ & & & $3.42(\mathrm{~m}, 1 \mathrm{H})$ & 77.0 \\
\hline $4^{\prime \prime \prime \prime}$ & & & $3.32(\mathrm{~m}, 1 \mathrm{H})$ & 70.9 \\
\hline $5^{\prime \prime \prime \prime}$ & & & $3.36(\mathrm{~m}, 1 \mathrm{H})$ & 76.8 \\
\hline $6^{\prime \prime \prime \prime}$ & & & $3.60(\mathrm{~m}, 1 \mathrm{H})$, & 61.2 \\
\hline
\end{tabular}

a assignments made on the basis of COSY, HSQC and HMBC correlations; ${ }^{b}$ Chemical shift values are in $\delta(\mathrm{ppm})$;

${ }^{\mathrm{c}}$ Coupling constants are in $\mathrm{Hz}$.

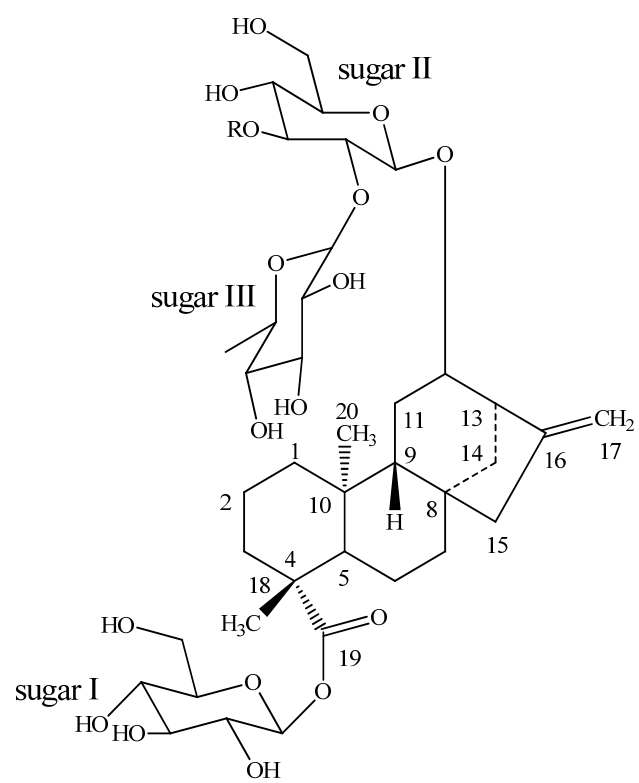

1: $\mathrm{R}=\mathrm{H}$

2: $\mathrm{R}=\beta$-D-glucopyranosyl

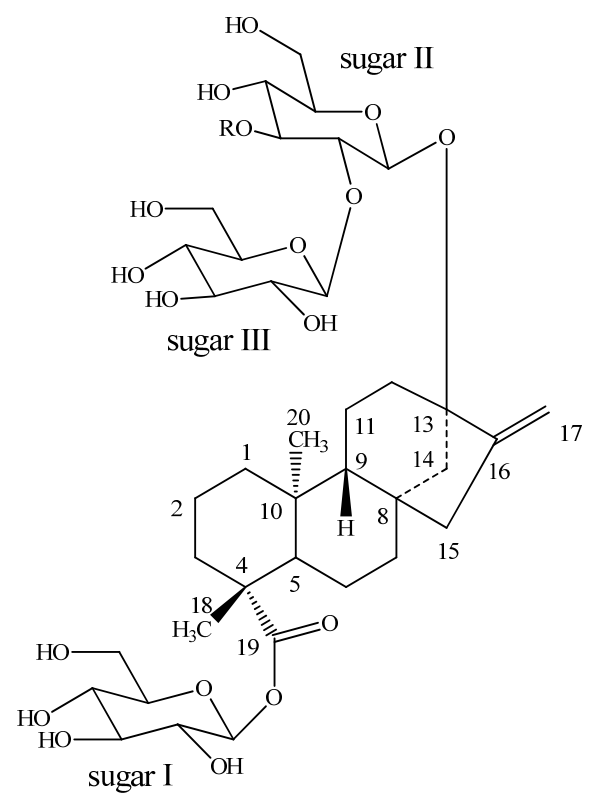

3: $\mathrm{R}=\mathrm{H}$ (stevioside)

4: $\mathrm{R}=\beta$-D-glucopyranosyl (rebaudioside-A)

Figure 1. Structures of 1-2 and other compounds 


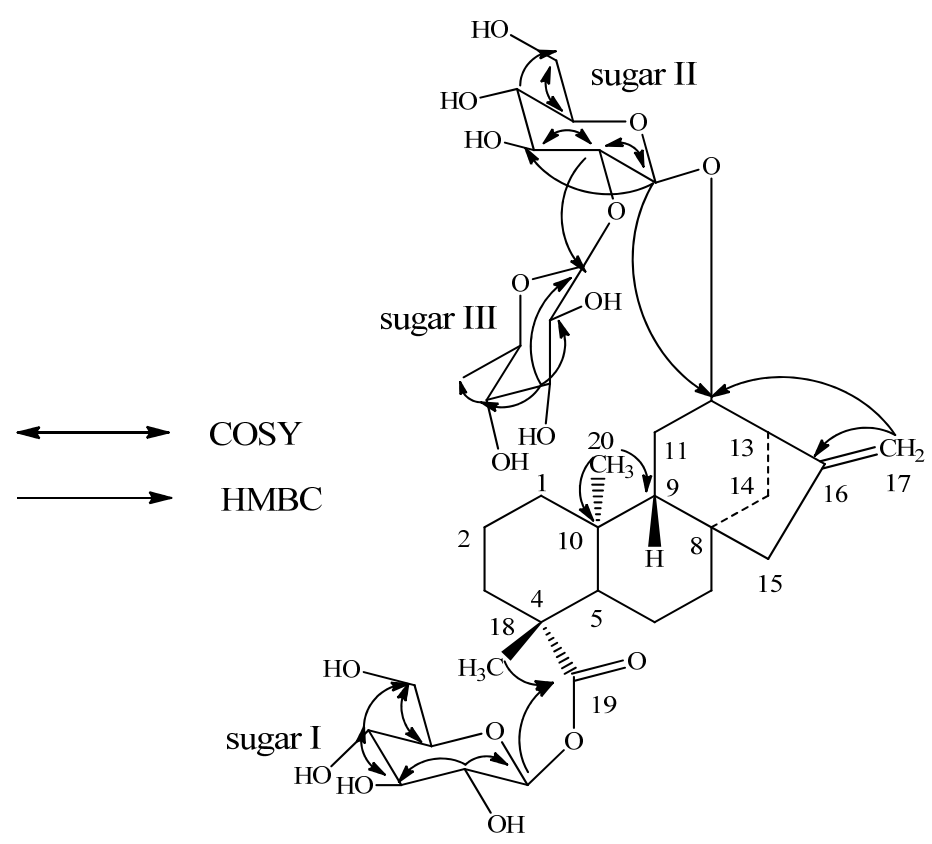

Figure 2. Key COSY and HMBC correlations of $\mathbf{1}$

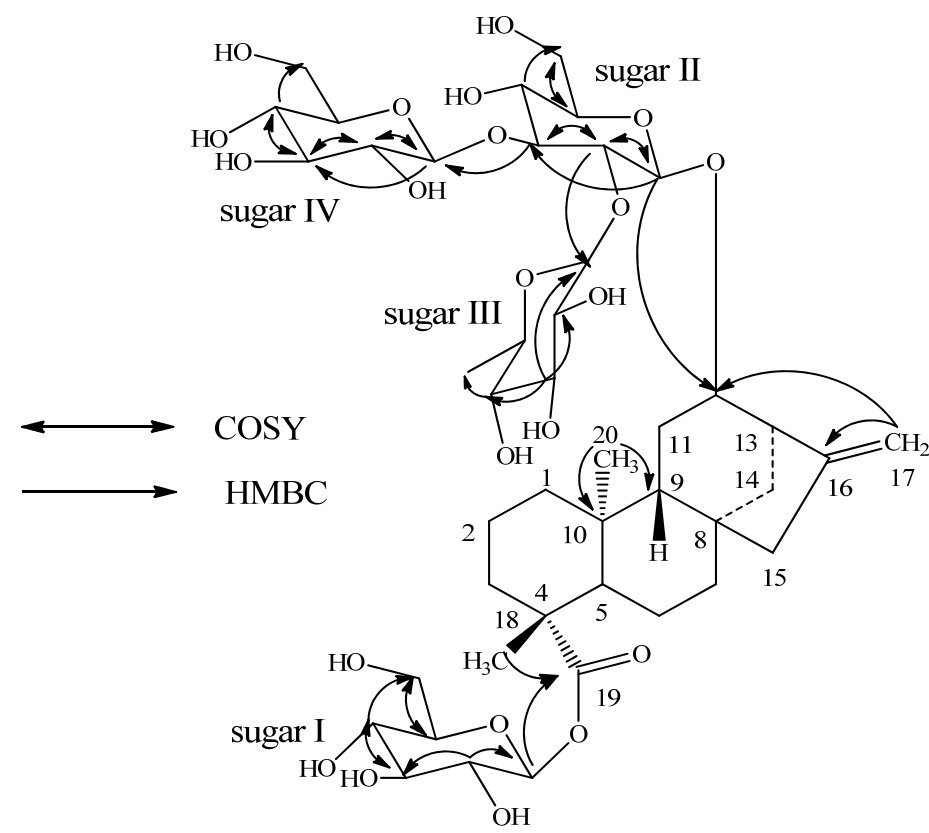

Figure 3. Key COSY and HMBC correlations of 2 